\title{
SEAWEED (HYPNEA SP.) SUPPLEMENTATION IN FEED PLAY ROLE IN BOOSTING IMMUNITY OF NILE TILAPIA (OREOCHROMIS NILOTICUS)
}

\author{
Mumtahina Mohammad, Nahid Sultana ${ }^{1}$, Anwara Begum ${ }^{2}$ \\ AND MD. NiAmUl NASER* \\ Department of Zoology, Faculty of Biological Sciences, University of Dhaka, Dhaka-1000, \\ Bangladesh
}

Keywords: Nile Tilapia, seaweed, blood serum, bactericidal activity, sensitive

Hypnea sp. is the most common economically potential seaweed species in Bangladesh. In this experiment, an initiative was taken to formulate fish feed using seaweed (Hypnea sp.) that can improve the immunity of Nile Tilapia, Oreochromis niloticus. Seaweed was supplemented in different percentages with commercial feed to evaluate their effects on their serum bactericidal activities. A 90-days experiment was conducted under five treatments $-\mathrm{T}_{1}\left(5 \%\right.$ seaweed), $\mathrm{T}_{2}$ (10\% seaweed), $\mathrm{T}_{3}$ (15\% seaweed), $\mathrm{T}_{4}(20 \%$ seaweed) and $\mathrm{C}$ (only commercial feed) with a replica for each. Fish blood was collected, serum was separated from blood and serum bactericidal activity was tested. Blood serum of $10 \%$ seaweed treated fish showed the highest sensitivity against three bacteria (Bacillus cereus, Salmonella typhimurium, Shigella flexneri) followed by $5 \%$ seaweed which showed sensitivity against Bacillus cereus and slightly against Salmonella typhimurium and Shigella flexneri and 15\% seaweed showed slight bactericidal activity against Bacillus cereus only, whereas, no bactericidal activity was observed for control and $20 \%$ seaweed treated fishes. The result indicates that the use of an optimum amount of seaweed supplements can improve the immunity system of Nile tilapia which can prevent the growth of bacteria and likely make fishes safe for human consumption.

\section{Introduction}

Sea is a unique reservoir with limitless possibilities. Seaweed is one such precious blessing of the sea and now it is considered as a door to the blue economy in Bangladesh ${ }^{(1)}$. 'Seaweed' is a colloquial term for the common name of countless species of mostly macroscopic, multicellular algae which do not have root system or flower, leaves, stems, fruits, and seed and generally, grow and live attached to rock or other hard substrata below high water mark or remain drifted in the ocean ${ }^{(2-7)}$. Seaweed farming is highly developed in many countries including Japan, China, Korea, Taiwan, the Philippines,

\footnotetext{
*Author for correspondence: <mnnaser@du.ac.bd>. 1Zoology Section, Bangladesh Council of Scientific \& Industrial Research, Dhaka-1205, Bangladesh. ${ }^{2}$ Department of Microbiology, University of Dhaka, Dhaka-1000, Bangladesh.
} 
Malaysia, Indonesia, and Thailand(8). About 221 species of commercially important seaweeds are found in south-east Asia. Among them, about 145 species are used for food and 110 species for phycocolloid (i.e., agar) production ${ }^{(9)}$ but the seaweed industry in Bangladesh is an initial stage though Bangladesh is rich with 133 species of seaweed, and eight of them are commercially important ${ }^{(10)}$. According to Zafar (1992) Caulerpa recemosa and Hypnea sp. are cultured at Saint Martin's island and Catenella nipae and Enteromorpha sp. are cultured at Fauzdarhat planted mangrove area in Bangladesh ${ }^{(11)}$. Among all species of seaweeds, Hypnea sp. is the most available and have a potential economic value. So, required steps has been taken by the Bangladesh government to study and utilize this seaweed.

The main use of the seaweed is as food. Seaweed has been used for many years in human nutrition, largely, as vitamin additive and feeding stuff for ruminants ${ }^{(12)}$. It has also medicinal value. Seaweed showed antibacterial activity in fish ${ }^{(13)}$. Nile Tilapia, Oreochromis niloticus is one of the most important fish species which is popularly cultured in all over Bangladesh because of its high market demand, less production cost, easy culture system, and good protein value. Therefore, an experiment was conducted to analyze the effects of seaweed (Hypnea sp.) supplementation on serum bactericidal activity of Nile tilapia fingerlings against Bacillus cereus, Vibrio cholerae, Salmonella typhimurium, Shigella flexneri, and Escherichia coli. Blood serum is the blood plasma excluding fibrinogens. It helps in innate type of defense mechanism of the body against bacteria. Serum bactericidal test is ordered to determine the maximum bactericidal dilution of serum after the administration of antibiotics. Fishes act as intermediate host, carrier, or vector of many bacteria. It is believed that seaweed (Hypnea sp.) had a chance to increase the immunity of Nile tilapia against different bacteria. Thus, in this study serum bactericidal activity test was conducted against five common bacteria to assess the protection from bacterial infection in fish.

\section{Materials and Methods}

The experiment was carried out in Zoology Section, Bangladesh Council of Scientific and Industrial Research (BCSIR) in Dhaka and Environmental Microbiology Laboratory, University of Dhaka. Tilapia fingerlings of 30 days were collected in polythene bags with oxygenated water from a hatchery of Bangladesh Fisheries Research Institute (BFRI), Mymensingh, and transported to BCSIR laboratory, Dhaka. Dried Hypnea sp. was collected from BFRI Marine Technology Station, Cox's Bazar which was then converted into powder and used as a supplementary feed with two types of commercial basal feed of Mega feed limited- nursery feed and floating feed. Nursery feed was given to the fingerlings for the first 7 days and then the floating feed was used.

Experimental design: Tilapia fingerlings were reared in the glass aquaria of volume $(30 \times 14 \times 6$ inches) for 3 months. The feeding trials were conducted on ten aquaria and 
groups of 30 tilapia fingerlings having similar body length and weight were selected and randomly stocked to each aquarium with a duplicate for each experimental diet. The fingerlings were fed on satiation in two times a day. Before stocking the fingerlings, each of the aquaria was cleaned up and prepared with all the facilities necessary to run the experiment efficiently. Each aquarium was filled with 60-liter clean tap water and water was changed once a week. To supply adequate oxygen into the aquaria, aeration was done properly by setting up an aerator in each aquarium. The feces and other dirt in each aquarium were removed and dead fingerlings were counted before feeding. Different water quality parameters such as water temperature, $\mathrm{pH}$, dissolved oxygen, turbidity, and conductivity were measured by Thermometer, pH meter (Jenway, Model 3020, UK), dissolved oxygen meter (Model Oxi 3150i, Germany), and Jenway 4510 conductivity meter respectively.

Five different experimental feed were given to the fingerlings where one was control (no supplement only basal feed) and the other four diets contained 5\%,10\%,15\% and 20\% seaweed supplementation with 95, 90, 85 and $80 \%$ basal feed for $\mathrm{T}_{1}, \mathrm{~T}_{2}, \mathrm{~T}_{3}$ and $\mathrm{T}_{4}$ respectively.

After 3 months, the fishes were collected. Then the fish serum sensitivities for different treatments were tested. The serum separation from blood samples were done in Zoology section, BCSIR and tests were done in the Environmental microbiology laboratory, University of Dhaka.

\section{Determination of fish serum sensitivity test against different pathogens}

Sample: Supplied fish serum

Culture: Bacillus cereus, Vibrio cholerae, Salmonella typhimurium, Shigella flexneri and Escherichia coli

Media: Nutrient agar

Reagents: Phosphate buffer and $0.1 \mathrm{~N} \mathrm{HCl}$

Equipment: Large Petri-dish, micropipette, pipette, Centrifuge machine, puller, conical flask, borer, incubator, inoculating loop, burner and test tubes.

Procedure: $1 \mathrm{ml}$ blood was collected from the freshly killed fishes of each aquarium using the disposable hypodermal syringe. Then collected blood was stored at $-20^{\circ} \mathrm{c}$ for several days. At the time of serum collection, the stored blood samples were kept at room temperature for melting. Then the blood samples were shaken to mix properly and allowed to clot by leaving them undisturbed at room temperature for 30 minutes. Samples were centrifuged at $8000 \mathrm{rpm}$ for $10 \mathrm{~min}$ which pulled the cells below the serum layer. The serum was then effectively sealed off from the cells. The Petri-plates were placed on a level bench and precautions were taken to keep the plate sterile. Then media seeded with bacterial suspension was poured in the Petri-plate using a circular motion to ensure the even distribution of medium over the plate and allowed to stand for a few 
minutes for solidification. For further solidification, the nutrient agar plate was kept in a refrigerator for a few minutes. Then using a sterile borer, 16 wells were designed in such a way that every well is apart from another by the same distance. $100 \mu \mathrm{l}$ of the test solutions were dropped in wells. After dropping the plate was kept undisturbed for about half an hour and then incubated at $37^{\circ} \mathrm{C}$ for $24 \mathrm{~h}$. After overnight incubation, the formation of any zone of growth inhibition was monitored.

\section{Results and Discussion}

Serum bactericidal activity is the capacity of blood serum to kill different bacteria and protect the body through increasing immunity from bacterial infection. In this experiment, five different bacteria (Bacillus cereus, Vibrio cholerae, Salmonella typhimurium, Shigella flexneri, and Escherichia coli) were used to analyze that if there is an effect of seaweed supplement on serum bactericidal activity of reared tilapia comparing with those fishes which were treated with control feed only (Table 1).

Table 1. Serum bactericidal activity of Nile tilapia treated with different percentages of seaweed supplemented feed.

\begin{tabular}{clllll}
\hline Treatments & Bacillus cereus & $\begin{array}{l}\text { Vibrio } \\
\text { cholerae }\end{array}$ & $\begin{array}{l}\text { Salmonella } \\
\text { typhimurium }\end{array}$ & Shigella flexneri & $\begin{array}{l}\text { Escherichia } \\
\text { coli }\end{array}$ \\
\hline $\mathrm{C}$ & Resistant & Resistant & Resistant & Resistant & Resistant \\
$\mathrm{C}$ & Resistant & Resistant & Resistant & Resistant & Resistant \\
$\mathrm{T}_{1}$ & Sensitive & Resistant & Slightly sensitive & Slightly sensitive & Resistant \\
$\mathrm{T}_{1 \mathrm{r}}$ & Sensitive & Resistant & Slightly sensitive & Slightly sensitive & Resistant \\
$\mathrm{T}_{2}$ & Sensitive & Resistant & Sensitive & Sensitive & Resistant \\
$\mathrm{T}_{2 \mathrm{r}}$ & Sensitive & Resistant & Sensitive & Sensitive & Resistant \\
$\mathrm{T}_{3}$ & Slightly & Resistant & Resistant & Resistant & Resistant \\
& sensitive & & & Resistant & Resistant \\
$\mathrm{T}_{3 \mathrm{r}}$ & Slightly & Resistant & Resistant & Resistant \\
& sensitive & & & Resistant & Resistant \\
$\mathrm{T}_{4}$ & Resistant & Resistant & Resistant & Resistant & Resistant \\
$\mathrm{T}_{4 \mathrm{r}}$ & Resistant & Resistant & & & \\
\hline
\end{tabular}

$\mathrm{C}=$ Control, $\mathrm{T}_{1}=5 \%$ Seaweed, $\mathrm{T}_{2}=10 \%$ Seaweed, $\mathrm{T}_{3}=15 \%$ seaweed, $\mathrm{T}_{4}=20 \%$ seaweed, $\mathrm{r}=$ replica.

Results showed that serum bactericidal activity was highest in $\mathrm{T}_{2}(10 \%$ seaweed as a supplement) where blood serum showed bactericidal activity against three bacteria (Bacillus cereus, Salmonella typhimurium, Shigella flexneri). Then $\mathrm{T}_{1}(5 \%$ seaweed as a supplement) showed serum bactericidal activity against Bacillus cereus and slightly against Salmonella typhimurium and Shigella flexneri. $\mathrm{T}_{3}$ (15\% seaweed as a supplement) showed slight bactericidal activity by blood serum against Bacillus cereus only. Control and T4 showed no serum bactericidal activity. The result indicated that the optimum amount of 
seaweed supplement increases the serum bactericidal activity, thus improve the defense mechanism of the body. As a supplementary feed, seaweed (Hypnea sp.) plays an important role to improve the immunity of Nile tilapia fingerlings only when the feed is supplied at an optimum rate. Excess supply of seaweed may have a negative impact on fish.

\section{Acknowledgement}

This research was supported by the R\&D project of BCSIR Laboratories, Dhaka and special thanks to Dr. Enamul Hoq, Chief Scientific Officer, BFRI, Cox's Bazar for his cordial assistance in seaweed collection.

\section{References}

1. Seraj S 2018. Seaweed door to blue economy. Daily Star. August 2, 2018

2. Chapman JV 1973. Seaweeds and Their Uses. Methuer and Co. ltd., India. pp. 299.

3. Santhanum R, N Ramanathan and G Jegatheesan 1990. Coastal Aquaculture in India. CBS Publishers and Distributions. India. pp. 180.

4. Okazaki A 1971. Seaweeds and Their Uses in Japan. Tokai University Press, Japan. pp. 170.

5. Round, F.E. 1970. The Biology of Algae. Edward Arnold (Publisher) Ltd. UK. pp.269.

6. McHugh DJ 2003. A Guide to Seaweed Industry. FAO, Rome, Italy. pp. 105.

7. National Ocean Service (Ocean service NOAA Govt.) of National Oceanic and Atmospheric Administration, 2005.

8. Ohno M 2004. Development of the seaweed cultivation and industry in Japan. Abstracts, 7th Asian Fisheries Forum 2004. P. 226.

9. Rudolph B 2000. Seaweed Products: Red Algae of Economic Significance. Marine and Freshwater Products Handbook. pp. 515-530.

10. Ahmed N and W Taparhudee 2010. Seaweed Cultivation in Bangladesh: Problems and Potentials. Kasetsart University Fisheries Research Bulletin No. 28 (2005): 13-21.

11. Zafar M 1992. Study on some hydro- biological aspects of the southeastern part of Bangladesh coastal waters in the Bay of Bengal. MSc Thesis. VUB Brussels. pp.258.

12. Asar M 1972. The Use of Some Weeds in Poultry Nutrition. Degree Diss., University of Alexandria, Egypt.

13. Bansemir A, M Blume, S Schroder and U Lindequist 2006. Screening of cultivated seaweeds for antibacterial activity against fish pathogenic bacteria. Aquaculture 252(1): 79-84. 